\title{
PELAKSANAAN KONSOLIDASI TANAH PERKOTAAN UNTUK PEMBANGUNAN JALAN BY PASS DI KOTA BUKITTINGGI*
}

\author{
ANA RAMADHONA \\ Sekolah Tinggi Ilmu Hukum Putri Maharaja \\ J1. Inai Belakang SPBU Koto Nan IV Payakumbuh \\ email: anas_mgjxiii@yahoo.com
}

\begin{abstract}
The increasing price of urban land causes the government difficulty in providing land for development. The status of land tenure will be more legal with the certificate as proof of ownership and ownership of land rights. Presidential Regulation no. 65 year 2006 stated that the procurement of land for the implementation of development for public interest by the government carried out by way of disposal or surrender of land rights. Article 18 of the UUPA explains that the revocation of a person's right to the land owned by the government shall only be exercised if the land is used for the common good including the interests of the nation and the state and the common interest of the people, the rights of the land may be revoked, compensating feasible as regulated by law. This study aims to find out how the implementation of land consolidation for the construction of By Pass in Bukittinggi City. To find out the obstacles faced by the local government of Bukittinggi city in the settlement. This research uses sociological juridical method, primary data in research is interview to informant and second data is library materials. The results show that the implementation of land consolidation of By Pass of Bukittinggi city has not been implemented maximally because the community has not fully understand the purpose and objectives of the implementation of land consolidation so that the people do not wholeheartedly implement it. Constraints faced in the completion of land consolidation for by-pass included the lack of public knowledge about land consolidation, the objections of some communities in handing over their consolidated land to the government and Most of the consolidated lands are customary soils together so it is a bit difficult in decision maker.
\end{abstract}

Keywords: Consolidation, Land, Development, Government, Society

\begin{abstract}
Abstrak
Meningkatnya harga tanah diperkotaan menyebabkan pemerintah kesulitan menyediakan tanah untuk pembangunan. Status penguasaan tanah akan lebih berkepastian hukum dengan sertipikat sebagai bukti penguasaan dan pemilikan hak atas tanah. Perpres No. 65 tahun 2006 dikatakan bahwa pengadaan tanah bagi pelaksanaan pembangunan untuk kepentingan umum oleh pemerintah dilaksanakan dengan cara pelepasan atau penyerahan hak atas tanah. Pasal 18 UUPA menjelaskan bahwa pencabutan hak seseorang terhadap tanah yang dimilikinya yang dilakukan oleh pemerintah hanya boleh dilakukan apabila tanah tersebut dipergunakan untuk kepentingan umum termasuk kepentingan bangsa dan negara serta kepentingan bersama dari rakyat, hak-hak atas tanah dapat dicabut, dengan memberi ganti kerugian yang layak yang diatur dengan undangundang. Penelitian ini bertujuan untuk mengetahui bagaimana pelaksanaan konsolidasi tanah untuk pembangunan jalan By Pass di Kota Bukittinggi. Untuk mengetahui kendala-kendala yang dihadapi oleh pemerintah daerah kota Bukttinggi dalam penyelesaian. Penelitian ini menggunakan metode yuridis sosiologis, data primer dalam penelitian adalah wawancara terhadap informan dan data sekunder adalah bahan-bahan kepustakaan. Hasil penelitian menunjukkan bahwa pelaksanaan konsolidasi tanah jalan By Pass kota Bukittinggi belum terlaksana secara maksimal karena masyarakat belum sepenuhnya paham dan mengerti mengenai maksud dan tujuan dari pelaksanaan konsolidasi tanah sehingga masyarakat tidak sepenuh hati melaksanakannya. Kendala-kendala yang dihadapi dalam penyelesaian konsolidasi tanah untuk jalan by pass antara lain minimnya pengetahuan masyarakat tentang konsolidasi tanah, adanya keberatan dari sebagian masyarakat
\end{abstract}

* Naskah diterima: 08 Sebtember 2017, direvisi: 10 Sebtember 2017, disetujui untuk terbit: 18 Sebtember 2017 
Ana Ramadhona: Pelaksanaan Konsolidasi Tanah Perkotaan Untuk Pembangunan Jalan ...

dalam menyerahkan tanahnya yang terkena konsolidasi kepada pemerintah dan Sebagian besar tanah-tanah yang terkena konsolidasi adalah tanah adat yang merupakan tanah milik bersama sehingga agak kesulitan dalam pengambilan keputusan.

Kata kunci: Konsolidasi, Tanah, Pembangunan, Pemerintah, Masyarakat

\section{PENDAHULUAN}

$\begin{array}{ccc}\text { Pada saat } & \text { sekarang } & \text { dalam } \\ \text { "pembangunan } & \text { nasional sangat }\end{array}$ memerlukan tanah tetapi kebutuhan tersebut tidak mudah untuk dipenuhi". ${ }^{1}$ PENGGUNAAN tanah harus disesuaikan dengan keadaan dan sifat dari hak itu, sehingga baik bagi kesejahteraan yang mempunyai tanah tersebut maupun yang bermanfaat bagi masyarakat dan negara. ${ }^{2}$

Usaha yang ditempuh oleh pemerintah di bidang pertanahan dalam pengadaan tanah dan untuk meningkatkan kualitas lingkungan di wilayah perkotaan atau permukiman, adalah dengan mengambil kebijaksanaan konsolidasi tanah perkotaan. Banyaknya kepentingan komponen dan kompleksnya pemanfaatan ruang di kawasan perkotaan menambah rumitnya permasalahan penataan ruang di kawasan perkotaan. Berkaitan dengan masalah tersebut, dibutuhkan suatu mekanisme perencanaan kawasan perkotaan dan pelaksanaannya yang dapat berjalan selaras dengan perkembangan dan pertumbuhan suatu kota. Konsolidasi tanah, mengupayakan penataan kembali penguasaan, pemilikan dan penggunaan tanah sesuai dengan tata ruang wilayah serta mengupayakan pengadaan tanah untuk pembangunan yang meningkatkan

\footnotetext{
${ }^{1}$ Soejono dan Abdurrahman, 2003, Prosedur Pendaftaran Tanah, Rineka Cipta, Jakarta, Hlm. 58

${ }^{2}$ Penjelasan Pasal 6 UUPA, HIm 38.
}

kualitas lingkungan hidup dan pemeliharaan sumber daya alam, dapat menjadi salah satu sarana pembangunan kawasan perkotaan. ${ }^{3}$

\begin{tabular}{lcrr}
\multicolumn{2}{c}{ Konsolidasi } & tanah & perkotaan \\
merupakan salah & satu & model \\
pembangunan yang & berkaitan & dengan \\
penyediaan tanah & untuk prasarana jalan \\
dan fasilitas & umum & dengan \\
mengikutsertakan & partisipasi & aktif
\end{tabular}
masyarakat dan pihak swasta, serta sebagai wujud nyata dalam pelaksanaan fungsi sosial atas tanah, dan mewujudkan lingkungan permukiman yang ATLAS (Aman, Tertib, Lancar, dan Sehat). Yang mana pelaksanaan konsolidasi tanah perkotaan ini secara fungsional dilaksanakan oleh Satuan Tugas Pelaksana Konsolidasi Tanah Perkotaan Kabupaten/ Kota yang dibentuk dengan Surat Keputusan Bupati/ Walikota.

"Konsolidasi tanah adalah suatu metode pembangunan yang merupakan salah satu kebijaksanaan pengaturan penguasaan tanah, penyesuaian penggunaan tanah dengan Rencana Tata Guna Tanah/Tata Ruang dan pengadaan tanah untuk kepentingan pembangunan serta kualitas lingkungan hidup/pemeliharaan sumber daya alam."4

\footnotetext{
${ }^{3}$ http://jembatan4.blogspot.co.id/2013/09/kon solidasi-tanah-dalam-penataan-ruang, diakses tanggal 3 september 2017

${ }^{4}$ Hasni, 2008, Hukum penataan Ruang dan Penatagunaan Tanah, Rajawali Pers, Jakarta, , HIm. 299
} 
Konsolidasi tanah perkotaan adalah menata persil-persil yang bentuknya tidak beraturan dalam lingkungan pemukiman atau yang direncanakan untuk pemukiman sehingga menjadi persil-persil teratur dan tertib yang semuanya menghadap jalan atau rencana jalan dan dilengkapi dengan penyelesaian tanah untuk sarana umum yang diperlukan sesuai dengan rencana umum tata ruang kota yang bersangkutan.

Ada beberapa manfaat yang diperoleh dari pelaksanaan konsolidasi tanah perkotaan yaitu:

1) "Meningkatkan pembangunan kota untuk memenuhi kebutuhan pertambahan penduduk yang cepat.

2) Menyediakan tanah bagi pembangunan untuk pemecahan problema pemukiman.

3) Menata pendaftaran dan mempebaiki problema yang berkaitan dengan kadaster.

4) Membatasi garis batas yang baru dan jelas bagi penguasaan tanah maksimum.

5) Melengkapi fasilitas umum perkotaan dan meningkatkan sistem-sistem saluran limbah serta sanitasi lingkungan.

6) Meningkatkan penggunaan tanah dan kedudukan hukum para pemilik tanah.

7) Memecahkan masalah penghuni liar dan memperindah lingkungan perkotaan.

8) Mengembangkan areal pemukiman masyarakat dan industri untuk kepentingan bisnis dan industri.
9) Menghemat dana pemerintah untuk pembangunan.

10) Menghindari kesulitan dana ganti rugi dalam memperoleh tanah untuk fasilitas umum.

11) Meningkatkan kemakmuran kota dengan sistem pajak.

12) Menimbulkan kepastian hukum atas pemilikan tanah karena setiap peserta konsolidasi seluruhnya mendapatkan tanda bukti atas tanah. ( sertifikat)". 5

Dalam Pasal 18 UUPA menjelaskan bahwa pencabutan hak seseorang terhadap tanah yang dimilikinya yang dilakukan oleh pemerintah hanya boleh dilakukan apabila tanah tersebut dipergunakan untuk kepentingan umum termasuk kepentingan bangsa dan negara serta kepentingan bersama dari rakyat, hak-hak atas tanah dapat dicabut, dengan memberi ganti kerugian yang layak yang diatur dengan Undang-Undang.

Dari ketentuan UUPA tersebut di atas, dapat ditemukan tiga unsur pokok, yaitu:

a. Kepentingan umum membutuhkan diadakannya pencabutan hak.

b. Pencabutan hak yang dilakukan harus dilakukan dengan pemberian ganti kerugian kepada yang berhak

c. Tindakan yang dilakukan didasarkan atas ketentuan Undang-Undang yang berlaku.

5 Juniarso Ridwan, 2008, Hukum Tata Ruang, nuansa, Bandung, Hlm. 51 
Ana Ramadhona: Pelaksanaan Konsolidasi Tanah Perkotaan Untuk Pembangunan Jalan ...

Dari penjelasan tersebut di atas, jelas bahwa pencabutan hak tidak berarti bahwa suatu hak akan dicabut begitu saja, tetapi diberikan suatu ganti kerugian yang layak. Tanah yang diperlukan untuk kepentingan umum tersebut "terlebih dahulu diusahakan agar tanah itu dapat diperoleh dengan persetujuan pemiliknya dengan cara jual beli, tukar menukar". 6 Sebelum lokasi konsolidasi tanah ditetapkan dengan Surat Keputusan Bupati/Walikota, salah satu persyaratan penetapan obyek konsolidasi tanah adalah adanya kesediaan pemilik tanah untuk menyetujui pelaksanaan konsolidasi tanah. Dengan kata lain menyetujui melepaskan sebagian hak atas tanahnya untuk disumbangkan dalam konsolidasi tanah tanpa ganti rugi berupa uang. Ganti rugi dalam konsolidasi tanah adalah ganti rugi berupa lingkungan yang tertata rapi, semua tanah menghadap ke jalan, terdapatnya fasilitas umum dan fasilitas sosial, dan kepastian hak atas tanah berupa sertipikat yang diperoleh secara cuma-cuma sebagai kompensasi atas tanah yang disumbangkan dalam konsolidasi tanah. Makna "menyetujui" adalah sepakat. Kesepakatan melahirkan perjanjian. Perjanjian menimbulkan perikatan, dan perikatan menimbulkan akibat hukum. Akibat hukum diatur dalam hukum perjanjian. Dengan kata lain

${ }^{6}$ Adrian Sutedi, 2007, Implementasi Prinsip Kepentingan Umum dalam Pengadaan Tanah Untuk Pembangunan, Sinar Grafika, Jakarta, Hlm. 88 perjanjian digunakan dalam konsolidasi tanah. $^{7}$

Untuk itu perlu diadakan perjanjian antara pemilik tanah dengan pemerintah yang melaksanakan pembebasan tanah sehingga nantinya tidak menimbulkan persengketaan di antara kedua belah pihak. Perjanjian itu haruslah sama-sama mengutamakan hak dan kewajiban dari masing-masing pihak agar tercipta suatu keadilan.

Pelepasan atau penyerahan hak atas tanah bagi pelaksanaan pembangunan jalan By pass kota Bukittinggi ini hendaknya dilakukan berdasarkan prinsip penghormatan terhadap hak atas tanah, artinya sekalipun kepentingan umum sangat menghendaki tanah yang bersangkutan harus diambil oleh negara, tetapi hak orang yang menjadi pemegang hak atas tanah harus tetap dihormati. Dalam pelaksanaannya pembangunan jalan By Pass Kota Bukitinggi menyebabkan timbulnya beberapa masalah dan persengketaan, terutama tentang pelaksanaan konsolidasi tanah yang dilakukan antara pemerintah dengan pemilik tanah, dan apa saja kendalakendala yang dihadapi dalam pelaksaan konsolidasi tanah untuk pembangunan jalan by pass di Kota Bukittinggi. penelitian ini bertujuan Untuk mengetahui bagaimana pelaksanaan konsolidasi tanah untuk pembangunan jalan By Pass di Kota Bukittinggi. Untuk mengetahui kendalakendala yang dihadapi oleh pemerintah

\footnotetext{
${ }^{7}$ https://gagasanhukum.wordpress.com/2009/ 01/05/tantangan-dan-hambatan-konsolidasi-tanahbagian-v.
} 
daerah kota Bukttinggi dalam penyelesaian konsilidasi tanah By pass Kota Bukittinggi. Sehubungan dengan hal tersebut diatas penulis tertarik untuk mengetahui bagaimana pelaksanaan konsolidasi tanah perkotaan dan kendalakendala yang dihadapi dalam pelaksanaannya sehingga penulisan karya ilmiah ini berjudul "PELAKSANAAN KONSOLIDASI TANAH PERKOTAAN UNTUK PEMBANGUNAN JALAN BY PASS DI KOTA BUKITTINGGI"

\section{METODE PENELITIAN}

Penelitian ini bersifat yuridis sosiologis. Pendekatan yuridis digunakan karena dari pelaksanaan konsolidasi tanah ini apakah telah sesuai dengan peraturan yang mengaturnya dan penelitian dilakukan di lapangan untuk memperoleh data primer dengan melalui wawancara terhadap informan. Disamping itu juga dilakukan penelitian terhadap bahanbahan kepustakaan untuk mendapatkan data sekunder.

\section{HASIL DAN PEMBAHASAN}

\section{A. Pelaksanaan Konsolidasi Tanah Perkotaan Untuk Pembangunan Jalan By Pass di Kota Bukittinggi}

\section{Penetapan Proyek}

Konsolidasi tanah diselenggarakan secara fungsional oleh Badan Pertanahan Nasional. Dalam penyelenggaraan konsolidasi tanah Kepala Kantor Pertanahan Kota Bukittinggi melakukan dan bertanggung jawab atas pelaksanaan penataan kembali penguasaan dan penggunaan tanah objek konsolidasi tanah.

Dalam Surat Keputusan Walikotamadya Kepala Daerah Tingkat II Bukittinggi dinyatakan bahwa pembangunan jalan Bukittinggi By Pass sepanjang 9,4 Kilometer dengan lebar jalan 26 meter akan dilaksanakan melalui tiga daerah kecamatan yang terdiri dari enam kelurahan, yaitu:

a. Kecamatan Mandiangin Koto Selayan, yang terdiri dari:

1. Kelurahan Kubu Gulai Bancah

2. Kelurahan Campago Ipuh

3. Kelurahan Mangis Gantiang

4. Kelurahan Pulai Anak Air.

b. Kecamatan Guguk Panjang, yang terdiri dari satu kelurahan yaitu Kelurahan Tarok Dipo.

c. Kecamatan Aur Bitugo Tigo Baleh yang terdiri dari satu kelurahan yaitu Kelurahan Aur Kuning.

d. Kegiatan konsolidasi tanah di kota Bukittinggi ini dilaksanakan dengan luas sebagai berikut:

Kegiatan konsolidasi tanah di kota Bukittinggi ini dilaksanakan dengan luas sebagai berikut:

\begin{tabular}{lll}
\hline Kelurahan & $\begin{array}{l}\text { Luas Tanah } \\
\text { Sebelum } \\
\text { Penataan } \\
(\mathbf{m} 2)\end{array}$ & $\begin{array}{l}\text { Luas Tanah } \\
\text { Setelah } \\
\text { Penataan } \\
(\mathbf{m} 2)\end{array}$ \\
\hline $\begin{array}{l}\text { Kubu Gulai } \\
\text { Bancah }\end{array}$ & 42.242 & 36.438 \\
Campago Ipuah & 97.030 & 82.476 \\
Mangis & 144.789 & 117.265 \\
Gantiang & & \\
Pulai Anak Air & 262.226 & 222.726 \\
Tarok Dipo & 82.820 & 78.950 \\
Aur Kuning & 88.857 & 74.834 \\
\hline
\end{tabular}


Ana Ramadhona: Pelaksanaan Konsolidasi Tanah Perkotaan Untuk Pembangunan Jalan ...

\section{Sosialisasi}

Sebelum dilakukan penyuluhan, perangkat kelurahan sebagai anggota Tim Koordinasi mengadakan pendataan namanama pemilik tanah yang termasuk dalam peserta konsolidasi tanah. Selanjutnya nama dari pemilik tanah dilaporkan kepada Ketua Tim Koordinasi. Para peserta konsolidasi diminta hadir pada pertemuan yang dilangsungkan pada masing-masing kelurahan untuk mendapatkan penyuluhan dan pengarahan dari pemerintah kota melalui Tim Koordinasi sehubungan dengan pembangunan jalan By Pass Bukittinggi serta pengadaan tanah dengan sistem konsolidasi. Pada pertemuan ini juga dilakukan musyawarah dengan para pemilik tanah untuk memperoleh persetujuannya dalam pengadaan tanah dengan sistem konsolidasi dan kesediaan untuk menyumbangkan sebagian kecil tanahnya secara sukarela untuk pembangunan jalan By Pass.

Sosialisasi atau penyuluhan dilaksanakan oleh pemerintah secara langsung. Penyuluhan diberikan kepada masyarakat terutama para pemilik tanah dilokasi konsolidasi tanah, pemuka masyarakat, ketua RW dan aparat pelaksana pada lokasi terpilih. Hal itu dimaksudkan agar masyarakat semakin mengerti tentang manfaat kegiatan konsolidasi tanah dan ikut secara aktif dalam pelaksanaannya. Penyuluhan kepada aparat pelaksana dimaksudkan agar aparat tersebut mengerti tugas dan tanggung jawab dalam melaksanakan kegiatan konsolidasi tanah. Adapun materi penyuluhannya secara umum yaitu kegiatan konsolidasi tanah secara umum, manfaat konsolidasi tanah bagi peserta konsolidasi, sumbangan peserta konsolidasi dalam konsolidasi tanah berupa sumbangan tanah untuk pelaksanaan dan lain-lain yang berkaitan dengan pelaksanaan konsolidasi tanah. tanahnya secara sukarela untuk pembangunan jalan By Pass.

Sosialisasi atau penyuluhan dilaksanakan oleh pemerintah secara langsung. Penyuluhan diberikan kepada masyarakat terutama para pemilik tanah dilokasi konsolidasi tanah, pemuka masyarakat, ketua RW dan aparat pelaksana pada lokasi terpilih. Hal itu dimaksudkan agar masyarakat semakin mengerti tentang manfaat kegiatan konsolidasi tanah dan ikut secara aktif dalam pelaksanaannya. Penyuluhan kepada aparat pelaksana dimaksudkan agar aparat tersebut mengerti tugas dan tanggung jawab dalam melaksanakan kegiatan konsolidasi tanah. Adapun materi penyuluhannya secara umum yaitu kegiatan konsolidasi tanah secara umum, manfaat konsolidasi tanah bagi peserta konsolidasi, sumbangan peserta konsolidasi dalam konsolidasi tanah berupa sumbangan tanah untuk pelaksanaan dan lain-lain yang berkaitan dengan pelaksanaan konsolidasi tanah.

\section{Pelaksanaan Pelepasan Hak dan Perjanjian Konsolidasi}

"Perjanjian adalah suatu peristiwa dimana seseorang berjanji kepada seseorang lain atau dimana dua orang itu saling berjanji untuk melaksanakan 
sesuatu hal". 8 Perjanjian itu haruslah sama-sama mengutamakan hak dan kewajiban dari masing-masing pihak agar tercipta suatu keadilan. "Keadilan sedikit banyaknya akan terwujud apabila pemerintah dalam melaksanakan kebijakannya itu didasarkan kepada etika kepentingan umum, terlebih lagi bila dibarengi dengan kesadaran administratif dalam pelaksanaannya". 9

Atas dasar kesepakatan yang telah terwujud, dilakukanlah pelepasan hak atas tanah-tanah yang berstatus tanah hak. Pelepasan dan penguasaan fisik tanahtanah yang menjadi objek konsolidasi tanah dilakukan dihadapan Kepala Kantor Pertanahan setempat.

Pelepasan hak dan penguasaan fisik tersebut dilakukan dengan membuat pernyataan tertulis, yang bentuk dan isinya ditetapkan oleh Kepala Badan Pertanahan Nasional. Pernyataan itu dilakukan secara kolektif oleh semua peserta menurut status tanahnya, yaitu pernyataan kolektif oleh sekelompok para pemegang hak atas tanah, yang masingmasing membubuhkan tanda tangannya. Pernyataan bukan hanya mengenai pelepasan hak atau penguasaan fisik tanahnya, melainkan juga menyebutkan syarat-syarat dan perjanjiannya sebagai mana yang dimuat dalam Desain pelaksanaan konsolidasi tanah.

8 Subekti, 1976, Hukum Perjanjian, PT Intermasa, Jakarta, Hlm. 1

9 Marmin M. Roosadijo, 1979, Tinjauan Pencabutan Hak-hak Atas Tanah dan Bendabanda yang Ada Diatasnya, Ghalia Indonesia, Jakarta, Hlm 23.
Kepala Kantor Pertanahan membubuhkan tanda tanganya pada tiap naskah pernyataan, setelah lengkap ditandatangani oleh segenap para peserta konsolidasi tanah, disertai pernyataan bahwa tanda tangan para peserta konsolidasi tanah tersebut dibubuhkan dihadapannya pada tanggal yang bersangkutan.

Oleh Kepala Kantor Pertanahan, dibuat risalah mengenai pernyataan yang dibuat dalam dua ganda. Berdasarkan Risalah Kantor Pertanahan dan Naskahnaskah Pernyataan tersebut, Kepala Kantor Wilayah BPN menerbitkan Surat Keputusan yang menerima pelepasan hak atas tanah-tanah hak yang bersangkutan dan menyatakan bahwa tanah-tanah tersebut, akan diperuntukkan sesuai apa yang disebut dalam disain pelaksanaan konsolidasi tanah yang telah disetujui bersama dan dikukuhkan oleh Kepala Badan Pertanahan.

Untuk mewujudkan maksud diatas, sebagai konsekwensinya para pemilik tanah sebagai pihak II (kedua) diminta:

a. "Kesediaanya untuk menyumbangkan sebagian tanahnya untuk kepentingan penataan dan fasilitas umum dan fasilitas sosial dengan persentase sesuai dengan kesepakatan yang diperjanjikan dikalikan dengan luas tanah dari masing-masing pemilik tanah".

b. Peserta konsolidasi menerima keadaan tanah yang telah dikonsolidasi karena tata letak tanahnya sudah diatur. 
Ana Ramadhona: Pelaksanaan Konsolidasi Tanah Perkotaan Untuk Pembangunan Jalan ...

Untuk mendapatkan bagaimana konsekwensi perjanjian tentang objek konsolidasi di lapangan di dapatkan datadata sebagai berikut, yakni dimana dari pelaksanaan perjanjian konsolidasi ini masyarakat peserta konsolidasi mengharapkan bahwa tanah mereka yang dikonsolidasikan tidak berubah status pemilikan hak atas tanah atau tidak mengurangi hak penguasaan atas tanah tersebut serta tidak akan mengurangi luas tanah masing-masing pemilik atau peserta konsolidasi, kecuali setelah dikurangi dengan keperluan jalan di lokasi tersebut sesuai dengan persentase dari kesepakatan yang telah di perjanjikan antara masyarakat dengan pemerintah.

\section{Pengkaplingan Tanah}

Pelaksanaan fisik desain konsolidasi tanah menghasilkan wilayah dengan penataan tanah-tanahnya dalam kaplingkapling yang teratur yang setelah diukur dan dipetakan menghasilkan peta pendaftaran tanah yang dimaksudkan. Dengan mengacu pada desain pelaksanaan konsolidasi tanah tersebut, sudah dapat diketahui masing-masing peserta konsolidasi tanah mendapat kapling yang sama, yang akan diberikan kepadanya dengan apa. Untuk itu kapling pun sudah dapat dibuat surat ukurnya.

Oleh karena itu, dapat segera diterbitkan Surat Keputusan pemberian Haknya oleh Kepala Kantor Wilayah BPN, yang menurut Peraturan Kepala BPN Nomor 4 Tahun 1991 dilakukan secara kolektif, dengan ketentuan khusus mengenai kewajiban finansial bagi penerima haknya yang semula berkedudukan sebagai pemegang hak atas tanah yang diserahkan sebagai objek konsolidasi.

Semuanya mengacu kepada desain pelaksanaan konsolidasi tanah yang bersangkutan. Kepada penerima hak perorangan kiranya akan diberikan hak milik. Jika berstatus badan hukum, akan diberikan hak guna bangunan dengan jangka waktu tiga puluh tahun.

\section{Pengukuran Pemetaan dan Pembukuan Tanah}

Data fisik tanah diperoleh dengan mengukur dan memetakan tanah-tanah yang bersangkutan, setelah lokasi dan batas-batasnya ditetapkan. "Pengukuran yang dilakukan yaitu pengukuran dan pemetaan keliling, pengukuran dan pemetaan rincikan, pengukuran blok plan atau desain tata ruang hasil pengukuran peta awal, pengukuran dan peta pengembalian atau peta penetapan."10 Kegiatan ini menghasilkan suatu peta yang melukiskan semua bidang tanah yang akan menjadi objek konsolidasi.

Peta yang dimaksudkan di atas kemudian ditempatkan di kantor kelurahan selama tiga bulan untuk memberi kesempatan kepada yang berkepentingan mengajukan keberatan. Keberatan-keberatan yang diajukan diusahakan untuk diselesaikan secara damai. Jika tidak mungkin didamaikan, yang bersangkutan boleh mengajukan ke pengadilan untuk menyelesaikan masalah tersebut.

${ }^{10}$ Hasil wawancara, sub konsolidasi tanah kantor BPN Bukittinggi. 
Data yang sudah tersedia itu dipergunakan sebagai data dasar untuk menerbitkan buku tanah dan sertifikat hak atas tanah-tanah hak yang bersangkutan karena tujuan pengumpulan data tersebut adalah dalam rangka membukukan untuk pertama kali hak-hak atas tanah yang ada di wilayah yang mengalami kegiatan pendaftaran secara lengkap.

Kegiatan Perpetaan dan pembukuan tanah yang merupakan kegiatan lanjutan dari pengukuran bidang tanah sangat diperlukan dalam rangka terciptanya kepastian hak dan tertib administrasi pertanahan. Bidang-bidang tanah yang telah diukur mengenai letak dan batasbatasnya dipetakan atau dimasukkan ke dalam peta pendaftaran atau kegiatan perpetaan dan bidang-bidang tanah tersebut dibukukan dalam suatu daftar yang disebut daftar tanah. Bidang-bidang tanah di dalam daftar tanah disusun berdasarkan nomor urut yaitu nomor identitas bidang atau NIB yang merupakan nomor identitas tunggal dari suatu bidang tanah. Dalam daftar tanah dicantumkan pula mengenai siapa yang menguasai atau pemilik tanahnya serta asal atau status tanah tersebut seperti tanah adat, tanah negara atau tanah yang telah memiliki sesuatu hak atas tanah termasuk data mengenai P4T (Penguasaan Pemilikan Pengunaan dan Pemanfaatan Tanah). Apabila data peta pendaftaran dan daftar tanah ini telah lengkap maka diharapkan pelayanan pertanahan dapat dilakukan lebih cepat dan lebih terjamin kepastian haknya. Kegiatan pengukuran perpetaan dan pembukuan tanah merupakan kegiatan untuk mendapatkan data awal yang sangat diperlukan untuk pelayanan di bidang pertanahan seperti yang telah diuraikan di atas.

\section{Penyerahan Sertifikat}

Sertifikat hanya boleh diserahkan kepada pihak yang namanya tercantum dalam buku tanah yang bersangkutan sebagai pemegang hak atau kepada pihak lain yang dikuasakan olehnya. Sertifikat merupakan surat tanda bukti hak yang berlaku sebagai alat pembuktian yang kuat mengenai data fisik dan data yuridis yang termuat didalamnya, sepanjang data tersebut sesuai dengan data yang ada dalam surat ukur dan buku tanah hak yang bersangkutan.

Dari gambaran data yang ada di bawah ini maka dapat dilihat berapa sertifikat yang sudah keluar dan berapa sertifikat yang belum keluar dari pelaksanaan konsolidasi tanah yang dilaksanakan di kota Bukittinggi, yaitu:

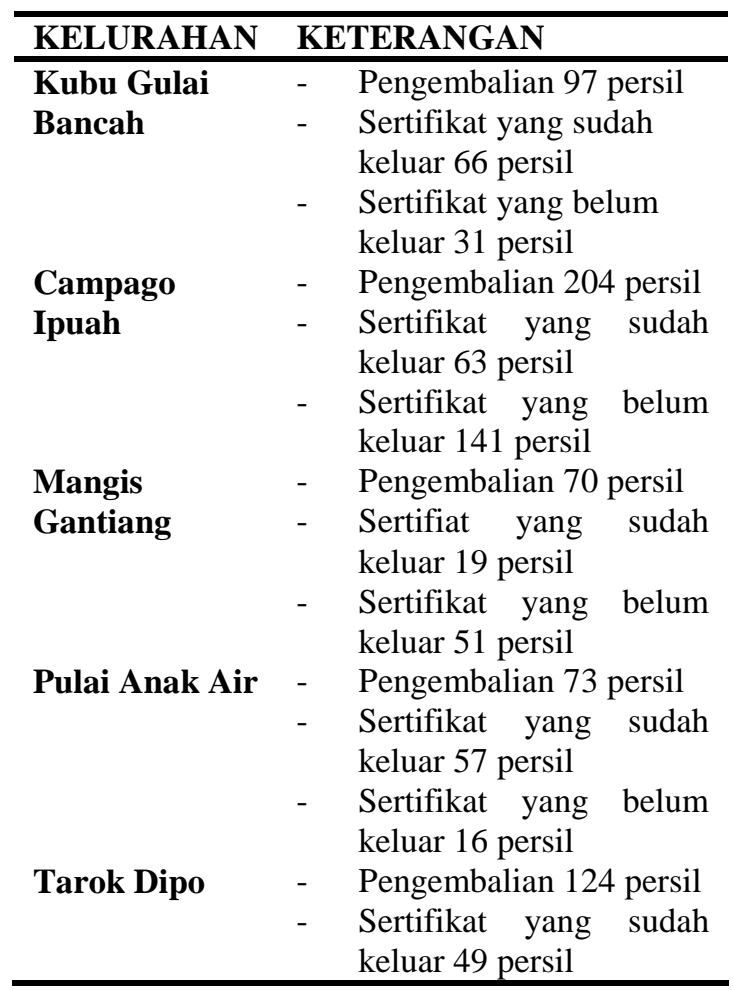


Ana Ramadhona: Pelaksanaan Konsolidasi Tanah Perkotaan Untuk Pembangunan Jalan ...

\section{B. Kendala-kendala yang dihadapi dalam Pelaksanaan Konsolidasi Tanah Perkotaan Untuk Pembangunan Jalan By Pass di Kota Bukittinggi}

Sebelum lokasi konsolidasi tanah ditetapkan dengan Surat Keputusan Walikota salah satu persyaratan penetapan objek konsolidasi tanah adalah adanya kesediaan pemilik tanah untuk menyetujui pelaksanaan konsolidasi tanah. Dengan kata lain menyetujui melepaskan sebagian hak atas tanahnya untuk disumbangkan dalam konsolidasi tanah tanpa ganti rugi berupa uang. Ganti rugi dalam konsolidasi tanah adalah ganti rugi berupa lingkungan yang tertata rapi, semua tanah menghadap kejalan, terdapatnya fasilitas umum dan fasilitas sosial, dan kepastian hak atas tanah berupa sertifikat sebagai kompensasi atas tanah yang disumbangkan dalam konsolidasi tanah.

Kendala- kendala yang dihadapi dalam pelaksanaan konsolidasi tanah di Kota Bukittinggi adalah:

1. Tanah yang dikonsolidasi merupakan tanah milik beberapa kaum. Untuk melaksanakan konsolidasi, harus mendapatkan kesepakatan dari setiap kaum dalam daerah yang dikonsolidasi. Kesepakan dari kaum ini sulit untuk didapatkan terutama yang berkaitan dengan besarnya persentase sumbangan tanah yang akan diberikan untuk konsolidasi sehingga kegiatannya akan memerlukan waktu yang cukup lama.

2. Masyarakat tidak mau menerima tanah hasil konsolidasi, karena tanah setelah konsolidasi kualitas tanahnya tidak sama dengan sebelum konsolidasi.

3. Sebagian masyarakat peserta konsolidasi belum ada kesepakatan atas pemegang hak sehingga terlambat menyerahkan alas hak. Dengan keterlambatan atau belum diserahkannya alas hak maka sertifikat dari pemilik tanah tidak dapat diterbitkan.

Disamping itu selain kendala yang dihadapi pemerintah seperti yang disebutkan diatas permasalahan juga terjadi pada "penetapan kavling tanah yang sulit dilakukan karena belum semua peserta konsolidasi menyetujui dilakukan konsolidasi terhadap tanahnya sehingga pengukuran dan penataan persil tanah juga sulit untuk dilakukan". ${ }^{11}$ Dan "masih ada masyarakat tidak menerima hasil penataan tanah awal, pendanaan yang kurang memadai serta masih adanya pihak-pihak tertentu yang berusaha untuk mendapatkan tanah pada lokasi strategis". 12

Banyaknya pemilik tanah mengeluhkan tentang batas-batas tanahnya setelah penataan karena kurangnya penjelasan dari pemerintah, tidak jelasnya batas-batas tanah dari pemilik tanah menimbulkan persengketaan antara sesama pemilik tanah sehingga sebagian pemilik tanah lebih cenderung mempertahankan batasbatas tanahnya sebelum konsolidasi.

\footnotetext{
11 Hasil wawancara dengan bagian Tata Pemerintahan.

12 Hasil wawancara dengan kepala sub Konsolidasi Tanah kantor BPN Bukittinggi
} 
Kenyataan seperti ini dapat dilihat dari adanya masyarakat pemilik tanah yang menjual tanahnya dan mendirikan bangunan di atas tanah yang bermasalah padahal konsolidasi tanah tersebut belum selesai dilaksanakan dan belum adanya kejelasan tentang batas-batas tanahnya setelah konsolidasi.

Kalaupun mereka telah mengetahui tentang batas-batas tanahnya setelah konsolidasi tetapi masih ada pemilik tanah yang lain tidak mau menyerahkan tanahnya setelah hasil dari konsolidasi karena merasa masih berhak atas tanah tersebut dan merasa berat untuk menerima pengurangan atas tanahnya. Inilah salah satu yang menjadi permasalahan kenapa sampai sekarang pelaksanaan konsolidasi tanah ini tidak kunjung selesai.

Disamping itu pelaksanaan perjanjian yang dilakukan antara pemerintah dengan pemilik tanah dimana masyarakat seharusnya mendapatkan tanah yang tertata rapi namum menurut peserta konsolidasi "pelaksanaannya sampai sekarang belum jelas dan selesai yakni dimana belum adanya jalan lingkung dilokasi konsolidasi dan sebagian dari peserta konsolidasi belum mendapatkan sertifikat atas tanahnya". 13

\footnotetext{
Sertifikat yang seharusnya didapatkan oleh peserta konsolidasi sampai sekarang masih ada yang belum menerimanya. Kalupun sudah ada sertifikat yang sudah selesai mereka enggan untuk menjemputnya ke Kantor Pertanahan karena mereka berdalih bahwa

13 Hasil wawancara dengan tokoh masyarakat di kelurahan Aur Kuning Bukittinggi.
}

sertifikat yang telah diterbitkan tidak sesuai dengan keadaan dilapangan salah satunya seperti salahnya pencantuman nama dari pemilik tanah yang sebenarnya.

\section{KESIMPULAN}

Berdasarkan uraian yang telah penilis kemukakan maka dapat penulis tarik kesimpulan sebagai berikut:

1. Proses pelaksanaan konsolidasi tanah jalan By Pass kota Bukittinggi tidak terlaksana dengan maksimal, karena ada bagian-bagian yang belum dilanjutkan.

2. Kendala-kendala yang dihadapi pemerintah kota Bukittinggi dalam upaya penyelesaian masalah konsolidasi antara lain karena minimnya pengetahuan masyarakat tentang tujuan dan manfaat dari konsolidasi tanah. Kemudian sebagian besar tanah-tanah terkena konsolidasimerupakan tanah ulayat yang kepemilikannya kolektif.

\section{SARAN}

1. Sebaiknya pemerintah kota Bukittinggi melaksanakan pembangunan jalan By Pass yang belum selesai dengan peraturan.

2. Pemerintah Koto Bukittinggi perlu melakukan sosialisasi atau penyuluhan yang lebih intensif dan untuk tanah ulayat yang terkena komsolidasi perlu duduk bersama untuk dapat memberikan kepastian kepada anggota kaum. 
Ana Ramadhona: Pelaksanaan Konsolidasi Tanah Perkotaan Untuk Pembangunan Jalan ...

\section{UCAPAN TERIMAKASIH}

Dengan mengucapkan Puji dan Syukur ke hadirat Allah SWT karena atas Rahmat dan Karunia-Nya, akhirnya penulis mampu menyelesaikan penulisan karya ilmiah ini yang berjudul: "PELAKSANAAN KONSOLIDASI TANAH PERKOTAAN UNTUK PEMBANGUNAN JALAN BY PASS DI KOTA BUKITTINGGI,

Penulis menyadari bahwa tulisan ini masih banyak kekurangannya karena itu tanpa bantuan dan dorongan dari berbagai pihak tidak mungkin karya ilmiah ini dapat diselesaikan. Oleh karena itu pada kesempatan ini dengan segala kerendahan hati, penulis ingin mengucapkan terimakasih dan penghargaan yang setinggi-tingginya kepada:

1. Bapak Dr.Eviandi Ibrahim S.H.,M.Hum selaku Ketua Sekolah Tinggi Ilmu Hukum Putri Maharaja Payakumbuh

2. Seluruh rekan-rekan Dosen Sekolah Tinggi Ilmu Hukum Putri Maharaja yang tidak dapat penulis sebutkan satu-persatu.

\section{DAFTAR PUSTAKA}

Adrian Sutedi, 2007, Implementasi Prinsip Kepentingan Umum dalam

\section{Pengadaan Tanah Untuk Pembangunan, Jakarta, Sinar Grafika.}

Hasni, 2008, Hukum penataan Ruang dan Penatagunaan Tanah, Rajawali Jakarta, Pers.

Subekti, 1976, Hukum Perjanjian, PT Intermasa, Jakarta,

Juniarso Ridwan, 2008, Hukum Tata Ruang, Bandung, nuansa.

Marmin M. Roosadijo, 1979, Tinjauan Pencabutan Hak-hak Atas Tanah dan Benda-banda yang Ada Diatasnya, Jakarta, Ghalia Indonesia.

Soejono dan Abdurrahman, 2003, Prosedur Pendaftaran Tanah, Jakarta, Rineka Cipta.

Undang-Undang No. 5 Tahun 1960 Tentang Pokok-Pokok Agraria.

Perpres No. 65 tahun 2006 tentang Pengadaan Tanah Bagi Pelaksanaan Pembangunan Untuk Kepentingan Umum

http://jembatan4.blogspot.co.id/2013/09/k onsolidasi-tanah-dalam-penataanruang,

https://gagasanhukum.wordpress.com/200 9/01/05/tantangan-dan-hambatankonsolidasi-tanah-bagian-v. 